\title{
Evidence That Phenylalanine May Not Provide the Full Needs for Aromatic Amino Acids in Children
}

\author{
JEAN W.-C. HSU, RONALD O. BALL, AND PAUL B. PENCHARZ
}

Departments of Nutritional Sciences [J.W.H., R.O.B., P.B.P.] and Paediatrics [P.B.P.], University of Toronto, Toronto, Ontario, Canada
M5S 3E2; The Research Institute [J.W.H, R.O.B., P.B.P.], The Hospital for Sick Children, Toronto, Ontario, Canada M5G $1 X 8 ;$
Department of Agricultural, Food, and Nutritional Sciences [R.O.B., P.B.P.], University of Alberta, Edmonton, Alberta, Canada T6G 2P5

\begin{abstract}
Phenylalanine is nutritionally classified as an indispensable amino acid and can be converted to tyrosine by phenylalanine hydroxylation. The initial goal of the present study was to determine the aromatic amino acid (phenylalanine plus tyrosine) requirements in healthy children fed a diet without tyrosine by using the indicator amino acid oxidation (IAAO) method using lysine as the indicator amino acid. Healthy school-age children $(n=5)$ were fed in random order a diet with eight graded intakes of phenylalanine without tyrosine. The requirement was determined by the rate of recovery of ${ }^{13} \mathrm{CO}_{2}$ from $\mathrm{L}-\left[1-{ }^{13} \mathrm{C}\right]$ lysine oxidation $\left(\mathrm{F}^{13} \mathrm{CO}_{2}\right)$. Phenylalanine (total aromatic amino acid) requirement, in the absence of tyrosine, for children was determined to be $28 \mathrm{mg} / \mathrm{kg} / \mathrm{d}$, which was only $64 \%$ of the adult requirement, which is biologically absurd. A possible reason for the lower estimate of phenylalanine requirement could be lower phenylalanine hydroxylation rate in children, which is supported by the finding of lower urinary tyrosine/phenylalanine ratios in children compared with adults. In conclusion, this study indicates that phenylalanine may not provide the total needs for aromatic amino acids in children fed an amino acid-based diet without tyrosine. (Pediatr Res 61: 361-365, 2007)
\end{abstract}

$\mathrm{P}$ henylalanine, an indispensable amino acid (1), either incorporates into protein or is converted to tyrosine. In addition to protein synthesis, tyrosine is also a precursor for catecholamine synthesis and serves as a substrate for thyroid hormone and melanin synthesis. Phenylalanine hydroxylation is an important step for both eliminating excess phenylalanine and providing tyrosine in the body. Tyrosine is considered a conditionally indispensable amino acid in preterm infants (2-4).

The current dietary reference intake (DRI) recommendation for the estimated average requirement (EAR) for total aromatic amino acids (phenylalanine + tyrosine) for school-age children is $33 \mathrm{mg} / \mathrm{kg} / \mathrm{d}$, based on adult amino acid requirements plus an estimate of that required for growth (5). The EAR for total aromatic amino acids for the healthy adult was

Received June 20, 2006; accepted October 19, 2006.

Correspondence: Paul B. Pencharz, M.D., Ph.D., Division of Gastroenterology, Hepatology, and Nutrition, The Hospital for Sick Children, 555 University Avenue, Toronto, Ontario, Canada M5G 1X8; e-mail: paul.pencharz@sickkids.ca

Supported by the Canadian Institute of Health Research (grant MOP-10321).

Presented in part in abstract form [Hsu J.W.-C., Ball R.O., Pencharz PB. (2005) Total aromatic amino acid requirements in healthy school-aged children determined by indicator amino acid oxidation (abstract). FASEB J 19:272.7]. Experimental Biology: 05: San Diego, CA.

DOI: $10.1203 / p d r .0 b 013 e 318030 d 0 d b$ estimated from the average of two very different estimates (15 and $39 \mathrm{mg} / \mathrm{kg} / \mathrm{d}$ ) in the current literature using stable isotope techniques. Therefore, both the adult EAR and the factorially calculated requirement for children are questionable. We have recently published studies, using lysine (6) and leucine (7) as indicator amino acids, and showed that adult aromatic amino acid requirements are $42-44 \mathrm{mg} / \mathrm{kg} / \mathrm{d}$. Furthermore, we have shown that the maintenance requirements for both the branched-chain amino acids and the sulfur amino acids are similar in children and adults $(8,9)$. If this relationship is the same for aromatic amino acids, the requirement for children would be predicted to be in the range of $42-44 \mathrm{mg} / \mathrm{kg} / \mathrm{d}$.

The only data in the current literature regarding aromatic amino acid requirements determined by stable isotope technique in children were the requirements for children with classic phenylketonuria (PKU) $(10,11)$. Phenylalanine and tyrosine requirements for children with classic PKU, determined by the IAAO technique, were estimated to be 14 and 19 $\mathrm{mg} / \mathrm{kg} / \mathrm{d}$, respectively $(10,11)$ with sum of $33 \mathrm{mg} / \mathrm{kg} / \mathrm{d}$. Clearly, these various estimates disagree substantially.

No data are currently available in healthy children for aromatic amino acid requirements using stable isotope techniques. The initial goal of this study was to estimate the total aromatic acid requirement in healthy children fed a diet without tyrosine, using the IAAO technique. The IAAO technique reflects the partitioning of a dietary essential amino acid (the indicator) between incorporation into protein (protein synthesis) and degradation (3). In an earlier study in adults, when dietary phenylalanine was held at $9.1 \mathrm{mg} / \mathrm{kg} / \mathrm{d}$, we were able to demonstrate a "requirement break-point for tyrosine" of $6 \mathrm{mg} / \mathrm{kg} / \mathrm{d}$ and hence a total aromatic amino acid requirement of $15.1 \mathrm{mg} / \mathrm{kg} / \mathrm{d}$ (5). This value is considerably less than our current estimates for total aromatic amino acid needs of $42-44 \mathrm{mg} / \mathrm{kg} / \mathrm{d}(8,9)$, and we interpreted the difference as being due to the limited amount of phenylalanine (9.1 $\mathrm{mg} / \mathrm{kg} / \mathrm{d}$ ) fed. Therefore, the IAAO method allows determination of the requirement of the test amino acid under the biologic and dietary conditions in force during the study. The current study was designed to determine total aromatic

Abbreviations: DRI, dietary reference intake; EAR, estimated average requirement; $\mathbf{F}^{\mathbf{1 3}} \mathbf{C O}_{\mathbf{2}}$, rate of ${ }^{13} \mathrm{CO}_{2}$ release from ${ }^{13} \mathrm{C}$-lysine; IAAO, indicator amino acid oxidation; LBM, lean body mass; PKU, phenylketonuria; RMR, resting metabolic rate 
amino acids in children, and we expected to find a value comparable with that determined in adults; as we have shown for the branched-chain amino acids and for the sulfur amino acids. However, when we found a biologically absurd value of $28 \mathrm{mg} / \mathrm{kg} / \mathrm{d}$, which was only $64 \%$ of the comparable value in adult of $42-44 \mathrm{mg} / \mathrm{kg} / \mathrm{d}$, we sought to find an explanation for this low value. Having considered all options, we came to the conclusion that the rate of phenylalanine hydroxylation in the children fed a tyrosinefree crystalline amino acid-based diet was limited so that protein synthesis was optimized at a level that was only $64 \%$ of that seen in adults. The clinical conclusion is that children receiving amino acid-based diets should always receive amino acid mixtures containing tyrosine.

\section{SUBJECTS AND METHODS}

Subjects. Five healthy children participated in the study on an outpatient basis in the Clinical Investigation Unit at The Hospital for Sick Children, Toronto, Ontario, Canada. Subject characteristics are described in Table 1. Subjects were excluded from the study if they had an inborn error of metabolism, a chronic disease, an endocrine disorder, unusual dietary practice, recent weight loss, pharmacologic therapy, or hormone treatment. The purpose of the study and the potential risks involved were explained in detail to each subject and their responsible caregivers, and written consent and assent were obtained from all participants and their responsible caregivers. All procedures used in the study were approved by the Research Ethics Board of The Hospital for Sick Children. All caregivers received financial compensation for transportation costs and time.

Experimental design. In the study, each subject received eight graded levels of phenylalanine intake $(5,10,20,30,40,50,60$, and $70 \mathrm{mg} / \mathrm{kg} / \mathrm{d})$ in random order on the study day. No tyrosine was supplied on the study day based on the assumption that phenylalanine can provide the entire requirement of tyrosine (12). Before the study, multiple skinfold thicknesses (triceps, biceps, subscapular, and suprailiac) were measured and bioelectrical impedance analysis was performed. Lean body mass (LBM) was calculated from reactance and resistance (13), measured by bioelectrical impedance analysis (BIA, model 101A; RJL Systems, Detroit, MI), and fat-free mass was calculated from density derived from the four-skinfold thickness (14), measured by a skinfold caliper (British Indicator, St. Albans, UK). Two days before each study day, subjects consumed a diet that provided adequate energy and protein intake at $1.5 \mathrm{~g} / \mathrm{kg} / \mathrm{d}$. Menu plans were provided according to typical food consumed by the subjects. Food records were collected to ensure consistency of dietary intake before the study day. Subjects' weight and height were measured on each IAAO study day. During each IAAO study day, the experiment lasted for $8 \mathrm{~h}$.

Table 1. Subject characteristics of the healthy children participating in the study

\begin{tabular}{lc}
\hline & Value* \\
\hline Age, $\mathrm{y}$ & $9.1 \pm 1.4$ \\
Weight, $\mathrm{kg}$ & $28.3 \pm 5.1$ \\
Height, $\mathrm{cm}$ & $134.1 \pm 10.2$ \\
\%IBW $\dagger$ & $93.3 \pm 13.7$ \\
Lean body mass $¥(\mathrm{~kg})$ & $23.7 \pm 3.6$ \\
Fat free mass§ $(\mathrm{kg})$ & $22.8 \pm 3.2$ \\
Resting metabolic rateII $(\mathrm{MJ} / \mathrm{d})$ & $4.92 \pm 0.55$ \\
Energy intake $\|(\mathrm{MJ} / \mathrm{d})$ & $8.36 \pm 0.94$
\end{tabular}

* Values are means $\pm \mathrm{SD}$ (standard deviation), $n=5$.

$\dagger$ IBW, ideal body weight, determined by actual body weight divided by matched weight (to actual height percentile) $\times 100$.

$\ddagger$ Determined from bioelectrical impedance analysis (13).

$\S$ Calculated from multiple skinfold thickness measurements (14).

If Measured using continuous, computerized, open-circuit indirect calorimetry.

$\|$ Calculated from resting metabolic rate multiplied by an activity factor of 1.7 .
Dietary intake and experimental diet. The experimental diet during each IAAO study provided energy (1.7 times resting metabolic rate) with $37 \%$ from fat, $52 \%$ from carbohydrate, and $10 \%$ from protein. During the course of the study, the energy was given at the level of multiplication of the resting metabolic rate (RMR) and an activity factor of 1.7 to ensure age-appropriate growth of the participating children. The subjects maintained their normal pattern of activity over the course of the study period. The RMR was determined after a 10- to 12-h overnight fast by continuous, open-circuit indirect calorimetry (2900 Computerized Energy Measurement SystemParamagnetic; Sensormedics, Yorba Linda, CA). Subjects consumed the isocaloric isonitrogenous hourly meals in a liquid formula (Protein-Free Powder, Product 80056, Mead Johnson, Evansville, IN; Tang and Koolaid, Kraft Foods, Toronto, Canada) with protein-free cookies, as previously described (15), for $8 \mathrm{~h}$, and each meal represented $1 / 12$ of the daily intake. The protein content was provided at a level of $1.5 \mathrm{~g} / \mathrm{kg} / \mathrm{d}$, given as a crystalline L-amino acid mixture based on the amino acid profile of egg protein. The lysine intake level on the study day was fixed at a level of 64 $\mathrm{mg} / \mathrm{kg} / \mathrm{d}$. Alanine was in various amounts to keep the meals isonitrogenous at different phenylalanine intakes.

Tracer protocol. The isotopic-labeled tracers used in the studies were $\mathrm{NaH}^{13} \mathrm{CO}_{3}$ with $99 \%$ enrichment and L- $\left[1-{ }^{13} \mathrm{C}\right]$ lysine $2 \mathrm{HCl}$ with $99 \%$ enrichment (Cambridge Isotope Laboratories, Woburn, MA). Isotopic and optical purity of L- $\left[1-{ }^{13} \mathrm{C}\right]$ lysine was verified by the manufacturer of the isotopes using chemical ionization gas chromatography-mass spectrometry and nuclear magnetic resonance. The enrichment of the L- $\left[1-{ }^{13} \mathrm{C}\right]$ lysine tracer was reconfirmed by liquid chromatography mass spectrometry of the butanol derivative. The measured fractional molar abundance of $\mathrm{L}-\left[1-{ }^{13} \mathrm{C}\right] l y$ sine was 99.5\%. The oral tracer study started after a 4-h enteral intake adaptation period. A primed dose of $\mathrm{NaH}^{13} \mathrm{CO}_{3}(2.023 \mu \mathrm{mol} / \mathrm{kg})$ and $\mathrm{L}-\left[1-{ }^{13} \mathrm{C}\right] \mathrm{lysine}$ $(16.305 \mu \mathrm{mol} / \mathrm{kg})$ were given with the fifth meal. In addition, the L-[1${ }^{13} \mathrm{C}$ llysine isotope $(8.153 \mu \mathrm{mol} / \mathrm{kg})$ was given with hourly meals, starting with the fifth meal, for the next $4 \mathrm{~h}$.

Sample collection. Breath and urine samples were collected on each IAAO study day. Three baseline breath samples were collected at 45,30 , and $15 \mathrm{~min}$, and two urine samples were collected at 45 and $15 \mathrm{~min}$ before the tracer protocol began. Because isotopic plateau in $\mathrm{CO}_{2}$ and urine are reached within $2 \mathrm{~h}$ after initiating isotope infusion (16), expired breath ${ }^{13} \mathrm{CO}_{2}$ and urine samples were collected every $30 \mathrm{~min}$, beginning $2.5 \mathrm{~h}$ after the tracer protocol began. The same pattern also was seen in the present study, and the slope of the plateau enrichment in breath samples was not significantly different from zero. The coefficient of variation between the four plateau values of breath enrichment was $2 \%$ to $5 \%$. Breath samples were collected in disposable Haldane-Priestley tubes (Venoject; Terumo Medical, Elkton, MD) using a collection mechanism that allowed the removal of dead-space air. The breath samples were stored at room temperature until ${ }^{13} \mathrm{C}$ enrichment analysis, and the urine samples were stored at $-20^{\circ} \mathrm{C}$ before analysis.

Analytical procedures. Expired ${ }^{13} \mathrm{CO}_{2}$ enrichment was measured by a continuous-flow isotope ratio mass spectrometry (CF-IRMS20/20, PDZ Europa, Cheshire, UK) and was expressed as atom percent excess against a reference standard of compressed $\mathrm{CO}_{2}$ gas.

Urinary L- $\left[1-{ }^{13} \mathrm{C}\right]$ lysine enrichment was measured by a triple quadrupole mass spectrometer API 4000 (Applied Biosystems/MDS SCIEX, Concord, ON, Canada) operated in positive ionization mode with TurbolonSpray ionization probe source (operated at $5800 \mathrm{~V}$ and $600^{\circ} \mathrm{C}$ ), which was coupled with an Agilent 1100 HPLC system (Agilent Technologies Canada Inc., Mississauga, ON). The detailed procedure was described in a previous study (6).

Urinary free amino acid concentrations were determined by highperformance liquid chromatography (HPLC) analysis. The urine samples plus norleucine (as the internal standard), were extracted using a cation exchange column (Dowex 50 W- $\times 8,100-200$ mesh $\mathrm{H}^{+}$form; Bio-Rad Laboratories, Hercules, CA). Urinary phenylalanine and tyrosine were derivatized with phenylisothiocyanate (adapted from PicoTag; Waters Corp., Milford, MA) (17-19), and their phenylisothiocyanate derivatives were separated and analyzed against a 18-amino-acid standard mix (Sigma Chemical Co., St. Louis, MO) by reversed-phase $(\mathrm{C} 18,2.9 \mathrm{~mm} \times 300 \mathrm{~mm}$ Pico Tag column, Waters Corp.) column using HPLC (Dionex Summit HPLC System, Dionex, Sunnyvale, CA; operated under HPLC pump model P580A LPG and UV/VIS 170S). The areas under the peaks were integrated using the Chromeleon software (version 6.2; Dionex, Oakville, ON, Canada).

Statistical analysis. The mean requirements for total aromatic amino acids were determined using a two-phase linear regression crossover model. This model allows a partition of the data points between two separate regression lines that minimize the residual error. This results in a crossover value that is termed the breakpoint. This breakpoint estimates the amino acid requirement of a sample population. Estimates of the mean aromatic amino acid requirement were derived by breakpoint analysis of the rate of release of ${ }^{13} \mathrm{CO}_{2}$ $\left(\mathrm{F}^{13} \mathrm{CO}_{2}\right)$ data using the mixed procedure of SAS (version 8.2, SAS Institute, 


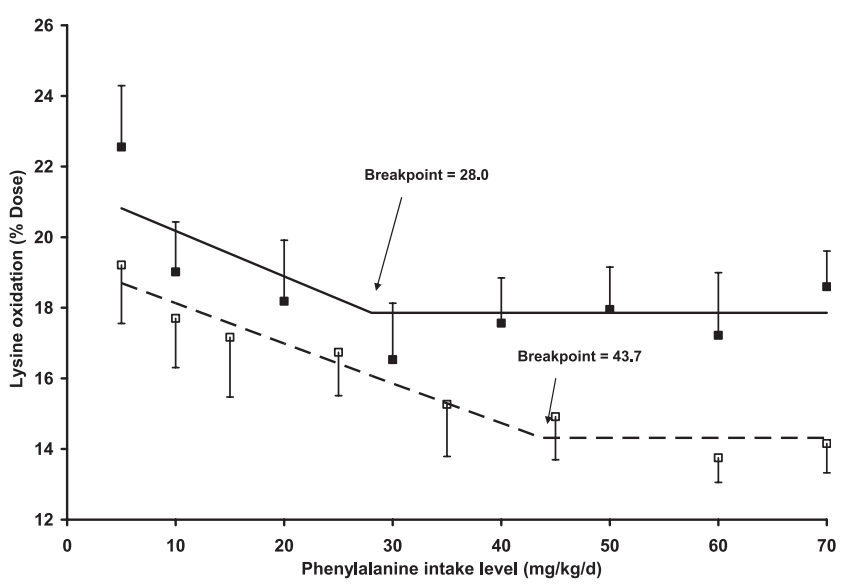

Figure 1. Effect of phenylalanine intake on lysine oxidation expressed as a percentage of dose in child ( $\square$ ) and adult ( $\square$ ) studies (6). Values are mean \pm standard error of the mean (SEM) at all tested phenylalanine intake levels, $n=5$. The intersection of two regression lines (breakpoint) represents the mean total aromatic amino acid requirement of $28.0 \mathrm{mg} / \mathrm{kg} / \mathrm{d}$ for children and $43.7 \mathrm{mg} / \mathrm{kg} / \mathrm{d}$ for adults (6). The breakpoint for children is significantly different from that for adults $(p<0.0001)$.

Cary, NC) (20) as described previously (21) (subject as a random effect) (Fig. 1). PROC MIXED was used to determine the effects of phenylalanine intake level on $\mathrm{F}^{13} \mathrm{CO}_{2}$ (Table 2). Subject was included as a random effect in the model, and the $p$ value was adjusted to the Tukey test for multiple comparisons. The statistical difference between the breakpoints of children and adults (6) was calculated post hoc using the comparison of a two-sample $t$ procedure $(22,23)$. The differences in the urinary tyrosine/phenylalanine concentration ratios between children and adults were analyzed by modeling urine as a function of intake and age group (adult versus child) using the mixed procedure of SAS. Group, group $\times$ intake, and group $\times$ intake (2) were included as fixed effects in the model, and the intercept was as a random effect. Differences were considered significant at $p<0.05$.

\section{RESULTS}

Body composition measures (weight, height, percentage of IBW, fat-free mass, and LBM) of the five children did not change over the study period (Table 1). Mean enrichment of ${ }^{13} \mathrm{CO}_{2}$ from L- $\left[1-{ }^{13} \mathrm{C}\right]$ lysine oxidation $\left(\mathrm{F}^{13} \mathrm{CO}_{2}\right)$ was affected by phenylalanine intake levels $(p=0.01)$ (Table 2). Phenylalanine intake did not affect lysine flux (data not shown). The mean total aromatic amino acid requirement determined by the two-phase linear regression crossover model was estimated to be $28.0 \mathrm{mg} / \mathrm{kg} / \mathrm{d}$, which was significantly lower than the requirement for adults $(44 \mathrm{mg} / \mathrm{kg} / \mathrm{d})(6,7)$ (Fig. $2 ; p<$ $0.0001)$. The reason for this lower estimate in children was not clear. Unfortunately, due to ethical constraints, we were not

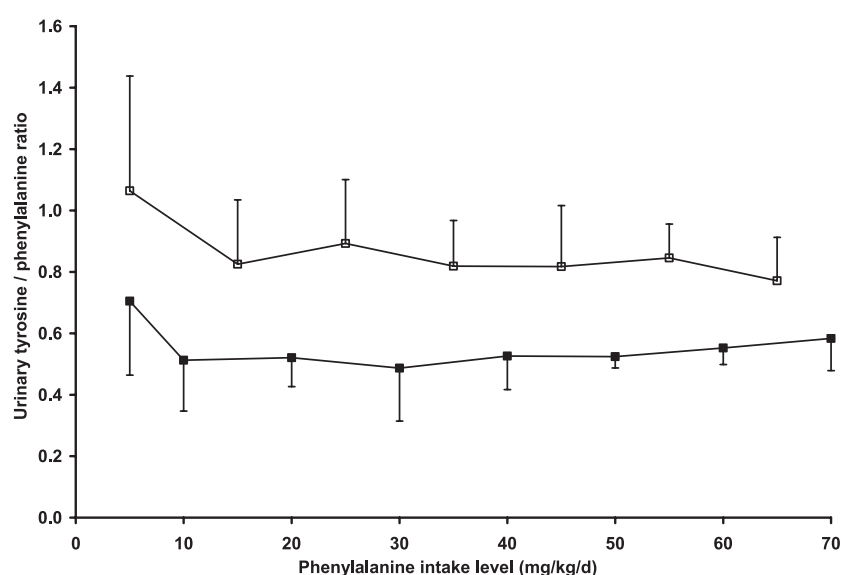

Figure 2. Effect of phenylalanine intake on urinary tyrosine/phenylalanine concentration ratio in child $(\square)$ and adult $(\square)$ studies. Values are mean \pm SD at all tested phenylalanine intake levels, $n=5$. Tyrosine/phenylalanine ratios of children in urine were significantly lower than those of adults $(p<0.0001)$.

able to collect blood samples from the children. However, we were able to compare urinary concentration for phenylalanine and tyrosine in our children with those derived from adults used in our previous experiment (7). Urinary tyrosine/ phenylalanine concentration ratios for children were significantly lower than those for adults ( Fig. 2; $p<0.0001$ ).

\section{DISCUSSION}

This is the first study using stable isotope techniques to estimate aromatic amino acid requirements in healthy children. The total aromatic amino acid requirement in this study was estimated to be $28 \mathrm{mg} / \mathrm{kg} / \mathrm{d}$. This value is only $64 \%$ of the recently estimated adult requirements $(42-44 \mathrm{mg} / \mathrm{kg} / \mathrm{d})$ using either leucine or lysine as the indicator amino acid $(6,7)$. The children used in this study had a lower percentage of body fat compared with the adults used in the previous study (6). However, when the mean aromatic amino acid requirement was expressed as per unit of LBM, the requirement for children $(34 \mathrm{mg} / \mathrm{kg} \mathrm{LBM} / \mathrm{d})$ was still $48 \%$ lower than that for adults $(55 \mathrm{mg} / \mathrm{kg} \mathrm{LBM} / \mathrm{d})(p<0.001)$. When compared with our estimated total aromatic amino acid requirement of 33 $\mathrm{mg} / \mathrm{kg} / \mathrm{d}$ for PKU children $(10,11)$, the present estimate is more similar, but still $15 \%$ lower. A lower requirement for aromatic amino acids for children compared with adults is biologically implausible.

Table 2. Individual $\mathrm{F}^{13} \mathrm{CO}_{2}$ data at all phenylalanine intake levels for healthy children participating in the study

\begin{tabular}{|c|c|c|c|c|c|c|c|c|}
\hline Subject & \multicolumn{8}{|c|}{ Phenylalanine intake, $\mathrm{mg} / \mathrm{kg} / \mathrm{d}$} \\
\hline & \multicolumn{8}{|c|}{$\mu \mathrm{mol} / \mathrm{kg} / \mathrm{h}$} \\
\hline 2 & 1.89 & 1.47 & 1.52 & 1.44 & 1.40 & 1.52 & 1.58 & 1.41 \\
\hline 3 & 1.45 & 1.40 & 1.49 & 1.33 & 1.14 & 1.57 & 1.32 & 1.61 \\
\hline 4 & 2.24 & 1.63 & 1.84 & 1.72 & 1.71 & 1.37 & 1.87 & 1.58 \\
\hline
\end{tabular}

* Mean with different superscript symbols are significantly different, $p<0.05$. By analysis of variance, phenylalanine intake significantly affects $\mathrm{F}^{13} \mathrm{CO}_{2}$ $(p=0.01)$. 
To date, our laboratory has published studies of the requirements in adults and children for the branched-chain amino acids $(8,24)$ and for the total sulfur amino acids $(9,25)$. In both cases, the estimate in children was the same as in adults, lending support to the concept that the maintenance component of essential amino acid requirements in children is the same as it is in adults. Hence, we were expecting the aromatic amino acid requirements in children to be similar to those in adults.

There are few possible explanations for the lower requirement estimate in children determined in the present study. The requirement for phenylalanine is the sum of the amount needed for protein synthesis plus the irreversible oxidative losses (26). The phenylalanine requirement in children with PKU represents only the amount of phenylalanine needed for protein synthesis. Because there are no data on obligatory oxidation for phenylalanine in children, we calculated the obligatory loss using the adult data (26\%) (27), which was approximately $4 \mathrm{mg} / \mathrm{kg} / \mathrm{d}$. Tyrosine requirement for children with classic PKU was determined to be $19 \mathrm{mg} / \mathrm{kg} / \mathrm{d}$ (10). Hence, the total aromatic amino acid (phenylalanine + tyrosine) requirements for healthy children were calculated to be approximately $37 \mathrm{mg} / \mathrm{kg} / \mathrm{d}$, which was the sum of phenylalanine requirement for children with classic PKU $(14 \mathrm{mg} /$ $\mathrm{kg} / \mathrm{d}$ ) (11) plus obligatory losses (4 mg/kg/d) plus $19 \mathrm{mg} / \mathrm{kg} / \mathrm{d}$ for tyrosine (10). This calculated estimate $(37 \mathrm{mg} / \mathrm{kg} / \mathrm{d})$ is comparable with the reported estimate for adults (42-44 $\mathrm{mg} / \mathrm{kg} / \mathrm{d})(6,7)$.

Differences in the diets for children and adults do not explain the difference in estimated aromatic amino acid requirement. All the indispensable amino acids were provided above adequate intakes in all the studies except the test amino acids, phenylalanine and tyrosine. The only sources of tyrosine on the study day were either from phenylalanine hydroxylation or tyrosine released by protein breakdown. There were differences between the children's and adult's intakes of energy (RMR $\times 1.7$ versus $\mathrm{RMR} \times 1.5$, respectively) and total protein $(1.5 \mathrm{~g} / \mathrm{kg} / \mathrm{d}$ and $1 \mathrm{~g} / \mathrm{kg} / \mathrm{d}$, respectively). Excess energy and protein intake are not believed to affect the estimation of aromatic amino acid requirements because the previously estimated branched-chain amino acid and total sulfur amino acid requirements for children and adults, by the IAAO technique, were comparable $(8,9,24,25)$.

Lysine oxidation (as percentage of dose) was higher for children than for adults at all phenylalanine intake levels (Fig. 2). The baseline (plateau) lysine oxidation in children was higher by $24 \%$. However, the higher baseline lysine oxidation cannot be ascribed to a higher total lysine intake (28) because these were not different. In addition, a difference in baseline does not affect the breakpoint estimate of requirement (23) unless a new amino acid becomes limiting after the phenylalanine requirement has been satisfied.

The tyrosine-to-phenylalanine concentration ratio in urine was measured to assess whether tyrosine could have become a limiting amino acid for protein synthesis, which changes inversely to indicator oxidation: the rates were lower in children than in adults (Fig. 2, $p<0.001$ ). A lower ratio indicates a lower rate of phenylalanine hydroxylation in children, and thus a lower rate of tyrosine synthesis. From this evidence, we suggest that tyrosine may have been limiting in the children in the current study.

Hydroxylation of phenylalanine to tyrosine is the first and rate-limiting step in phenylalanine catabolic pathway. It is an important step for both eliminating excess phenylalanine and providing tyrosine to the body tissues when tyrosine dietary intake is low. Phenylalanine hydroxylase activity increases with age in rats and reaches a maximum in the young adult at an age of 50-60 d (29). Unfortunately, the rate of phenylalanine hydroxylation in healthy children has not been reported.

Phenylalanine hydroxylase activities have been found in human fetal liver at an early stage of development (30). Phenylalanine hydroxylation has been suggested to be limiting in the preterm infant $(2,4)$. In contrast, Kilani et al. (31) showed that neonates were capable of converting phenylalanine to tyrosine. The rate of phenylalanine hydroxylation in the fasting state in infants with mean gestation age of $28-30 \mathrm{wk}(6.0$ $\mu \mathrm{mol} / \mathrm{kg} / \mathrm{h})(31)$ was similar to that in adults $(5.8 \mu \mathrm{mol} / \mathrm{kg} / \mathrm{h})$ (32). The phenylalanine hydroxylation rates in neonates receiving a moderate parenteral phenylalanine intake ranged from 11 to $22 \mu \mathrm{mol} / \mathrm{kg} / \mathrm{h}$ (33-35). When neonates received an increased parenteral phenylalanine intake, the rate of phenylalanine hydroxylation increased to greater than $35 \mu \mathrm{mol} / \mathrm{kg} / \mathrm{h}$ (35-37), and alternate catabolites of phenylalanine and tyrosine were found in urine in neonates receiving the higher phenylalanine intakes (35). The rates need to be interpreted carefully because at high phenylalanine intakes, this tracer model of phenylalanine hydroxylation may overestimate actual hydroxylation rate (38). Because these neonates were capable of converting phenylalanine to tyrosine by phenylalanine hydroxylation, we must assume that children are capable of converting phenylalanine to tyrosine. Unfortunately, there are no data in the literature for hydroxylation rate in children receiving graded phenylalanine intakes.

In summary, the mean phenylalanine requirement, in the absence of tyrosine, for healthy children was determined to be $28.0 \mathrm{mg} / \mathrm{kg} / \mathrm{d}$, which was $64 \%$ of that for adults, which is biologically implausible. We explored various explanations, and the only one with any evidence to support it is that phenylalanine hydroxylation may be limiting in children fed a tyrosine-free diet. The lower urinary tyrosine/phenylalanine ratios in children at graded phenylalanine intakes implied that phenylalanine hydroxylation may be limited. In conclusion, this study indicates that phenylalanine alone may not provide the needs of aromatic amino acids in children fed a diet without tyrosine. Further investigation of effects of phenylalanine intakes on phenylalanine hydroxylation rates in children is needed. A clinical consequence of this study is that children receiving amino acid-based diets should always receive tyrosine containing amino acid mixtures.

Acknowledgments. The authors thank Mahroukh Rafii for technical assistance (The Hospital for Sick Children, Toronto, ON, Canada). They thank Karen Chapman for coordinating the activity in the Clinical Investigation Unit of The Hospital for Sick Children and Linda Chow for preparing the proteinfree cookies. Special thanks to the subjects who participated in 
this study and their parents. They are also grateful to Mead Johnson Nutritionals (Canada) for providing the protein-free powder for the experimental diet.

\section{REFERENCES}

1. Womack M, Rose WC 1934 Feeding experiments with mixtures of highly purified amino acids. VI. The relation of phenylalanine and tyrosine to growth. J Biol Chem 107:449-458

2. Laidlaw SA, Kopple JD 1987 Newer concepts of the indispensable amino acids. Am J Clin Nutr 46:593-605

3. Pencharz PB, Ball RO 2003 How to assess amino acid requirement (with particular reference to inborn errors of amino acid metabolism). In: Bachmann C, Koletzko B (eds) Genetic Expression and Nutrition, Nestle Nutrition Workshop Series, Pediatric Program. Vevey/Lippincott, Williams \& Wilkins, Philadelphia, pp 37-50.

4. Pencharz PB, House JD, Wykes LJ, Ball RO 1996 What are the essential amino acids for the preterm and term infant? In: Bindels JB, Goedhart AC, Visser HK (eds) Recent Developments in Infant Nutrition, 10th Nutricia Symposium. Kluwer Academic Publishers, Dordrecht, The Netherlands, pp 278-296.

5. Institute of Medicine 2002 Dietary Recommended Intakes: Energy, Carbohydrate, Fiber, Fat, Fatty Acids, Cholesterol, Protein and Amino Acids. Institute of Medicine, National Academy Press, Washington DC, pp 589-768.

6. Hsu JW, Goonewardene LA, Rafii M, Ball RO, Pencharz PB 2006 Aromatic amino acid requirements in healthy men measured by indicator amino acid oxidation. Am J Clin Nutr 83:82-88

7. Hsu JW, Kriengsinyos W, Wykes LJ, Rafii M, Goonewardene LA, Ball RO, Pencharz PB 2006 Leucine is not a good choice as an indicator amino acid for determining amino acid requirements in men. J Nutr 136:958-964

8. Mager DR, Wykes LJ, Ball RO, Pencharz PB 2003 Branched-chain amino acid requirements in school-aged children determined by indicator amino acid oxidation (IAAO). J Nutr 133:3540-3545

9. Turner JM, Humayun MA, Elango R, Rafii M, Langos V, Ball RO, Pencharz PB 2006 Total sulfur amino acid requirement of healthy school-age children as determined by indicator amino acid oxidation technique. Am J Clin Nutr 83:619-623

10. Bross R, Ball RO, Clarke JT, Pencharz PB 2000 Tyrosine requirements in children with classical PKU determined by indicator amino acid oxidation. Am J Physiol Endocrinol Metab 278:E195-E201

11. Courtney-Martin G, Bross R, Raffi M, Clarke JT, Ball RO, Pencharz PB 2002 Phenylalanine requirement in children with classical PKU determined by indicator amino acid oxidation. Am J Physiol Endocrinol Metab 283:E1249-E1256

12. Rose WC, Leach BE, Coon MJ, Lambert GF 1955 The amino acid requirements of man. IX. The phenylalanine requirement. J Biol Chem 213:913-922

13. Houtkooper LB, Going SB, Lohman TG, Roche AF, Van Loan M 1992 Bioelectrical impedance estimation of fat-free body mass in children and youth: a cross-validation study. J Appl Physiol 72:366-373

14. Brook CG 1971 Determination of body composition of children from skinfold measurements. Arch Dis Child 46:182-184

15. Zello GA, Pencharz PB, Ball RO 1990 The design and validation of a diet for studies of amino acid metabolism in adult humans. Nutr Res 10:1353-1365

16. Bross R, Ball RO, Pencharz PB 1998 Development of a minimally invasive protocol for the determination of phenylalanine and lysine kinetics in humans during the fed state. J Nutr 128:1913-1919

17. Bidlingmeyer BA, Cohen SA, Tarvin TL 1984 Rapid analysis of amino acids using pre-column derivatization. J Chromatogr 336:93-104
18. Cohen SA, Bidlingmeyer BA, Tarvin TL 1986 PITC derivatives in amino acid analysis. Nature 320:769-770

19. Cohen SA, Strydom DJ 1988 Amino acid analysis utilizing phenylisothiocyanate derivatives. Anal Biochem 174:1-16

20. Littell RC, Milliken GA, Stroup WW, Wolfinger RD, Schabenberger O 2006 SAS System for Mixed Models. SAS Institute, Cary, NC, pp 159-204.

21. Zello GA, Pencharz PB, Ball RO 1993 Dietary lysine requirement of young adult males determined by oxidation of L-[1-13C]phenylalanine. Am J Physiol 264:E677E685

22. Pagano M, Gauvreau K 2000 Principles of Biostatistics. Duxbury Thomson Learning, Pacific Grove, CA, pp 259-284.

23. Kriengsinyos W, Wykes LJ, Ball RO, Pencharz PB 2002 Oral and intravenous tracer protocols of the indicator amino acid oxidation method provide the same estimate of the lysine requirement in healthy men. J Nutr 132:2251-2257

24. Riazi R, Wykes LJ, Ball RO, Pencharz PB 2003 The total branched-chain amino acid requirement in young healthy adult men determined by indicator amino acid oxidation by use of L-[1-13C]phenylalanine. J Nutr 133:1383-1389

25. Di Buono M, Wykes LJ, Ball RO, Pencharz PB 2001 Total sulfur amino acid requirement in young men as determined by indicator amino acid oxidation with L-[1-13C]phenylalanine. Am J Clin Nutr 74:756-760

26. Fuller MF, Garlick PJ 1994 Human amino acid requirements: can the controversy be resolved? Annu Rev Nutr 14:217-241

27. Zello GA, Pencharz PB, Ball RO 1990 Phenylalanine flux, oxidation, and conversion to tyrosine in humans studied with L-[1-13C]phenylalanine. Am J Physiol 259:E835-E843

28. Meredith CN, Wen ZM, Bier DM, Matthews DE, Young VR 1986 Lysine kinetics at graded lysine intakes in young men. Am J Clin Nutr 43:787-794

29. Freedland RA, Krakowski MC, Waisman HA 1962 Effect of age, sex, and nutrition on liver phenylalanine hydroxylase activity in rats. Am J Physiol 202:145-148

30. Jakubovic A 1971 Phenylalanine-hydroxylating system in the human fetus at different developmental ages. Biochim Biophys Acta 237:469-475

31. Kilani RA, Cole FS, Bier DM 1995 Phenylalanine hydroxylase activity in preterm infants: is tyrosine a conditionally essential amino acid? Am J Clin Nutr 61:12181223

32. Clarke JT, Bier DM 1982 The conversion of phenylalanine to tyrosine in man. Direct measurement by continuous intravenous tracer infusions of L-[ring2H5]phenylalanine and L-[1-13C] tyrosine in the postabsorptive state. Metabolism 31:999-1005

33. Clark SE, Karn CA, Ahlrichs JA, Wang J, Leitch CA, Leichty EA, Denne SC 1997 Acute changes in leucine and phenylalanine kinetics produced by parenteral nutrition in premature infants. Pediatr Res 41:568-574

34. Denne SC, Karn CA, Ahlrichs JA, Dorotheo AR, Wang J, Liechty EA 1996 Proteolysis and phenylalanine hydroxylation in response to parenteral nutrition in extremely premature and normal newborns. J Clin Invest 97:746-754

35. Roberts SA, Ball RO, Filler RM, Moore AM, Pencharz PB 1998 Phenylalanine and tyrosine metabolism in neonates receiving parenteral nutrition differing in pattern of amino acids. Pediatr Res 44:907-914

36. Castillo L, Yu YM, Marchini JS, Chapman TE, Sanchez M, Young VR, Burke JF 1994 Phenylalanine and tyrosine kinetics in critically ill children with sepsis. Pediatr Res 35:580-588

37. Shortland GJ, Walter JH, Fleming PJ, Halliday D 1994 Phenylalanine kinetics in sick preterm neonates with respiratory distress syndrome. Pediatr Res 36:713-718

38. House JD, Thorpe JM, Wykes LJ, Pencharz PB, Ball RO 1998 Evidence that phenylalanine hydroxylation rates are overestimated in neonatal subjects receiving total parenteral nutrition with a high phenylalanine content. Pediatr Res 43:461-466 